\title{
DIVERSITY OF DIPTERA AND THEIR CONTRIBUTION IN THE ASSESSMENT OF THE ECOLOGICAL QUALITY OF DALOA'S URBAN AQUATIC ECOSYSTEMS (WEST-CENTRAL COTE D'IVOIRE)
}

\author{
K.R Djene ${ }^{1 *}$, K. Y Bony ${ }^{2}$, J.R Allouko ${ }^{3}$, A. Kressou ${ }^{4}$ and A.S. N'guessan ${ }^{5}$ \\ Laboratoire de Biodiversité et Ecologie Tropicale, UFR de l'Environnement, \\ Université Jean Lorougnon Guédé (Daloa)
}

Article History: Received 02 ${ }^{\text {th }}$ July 2021; Accepted $17^{\text {th }}$ August 2021; Published $31^{\text {st }}$ August 2021

\begin{abstract}
The present study deals with the use of the little-known macro invertebrate Diptera in assessing the state of biotic integrity of Daloa's urban water bodies. Thus, aquatic macro invertebrates were sampled at a seasonal rate on 24 identified stations. The inventory showed 13128 macro invertebrate individuals of 208 taxa divided into 7 classes, 21 orders and 84 families. The Diptera is represented by 1987 individuals of 53 taxa from 16 families. Analysis of the Shannon index values shows that Rice Pond 1 and Gbedji Lake is the least diversified and balanced stations. The relative percentage of Diptera was recorded with values below $75 \%$, thus reflecting two categories of stations: stations with moderate pollution and undisturbed stations.
\end{abstract}

Keywords: Macro invertebrates, Diptera, Biotic integrity, Pollution, Daloa, Côte d'Ivoire.

\section{INTRODUCTION}

In general, water resources seem increasingly threatened by a qualitative deterioration (Gire, 2001). Long neglected by managers, wetlands are of growing interest in relation to the conservation of aquatic biodiversity (Oertli et al., 2005). Indeed, aquatic ecosystems host an exceptional diversity of flora and fauna (Davies et al., 2008). These aquatic environments are particularly threatened by increasing urbanization and agriculture (Oertli et al., 2005). The ecological degradation of aquatic ecosystems in urban areas is observed by various ecological and physical indicators: loss of biodiversity, shoreline erosion, high nutrient concentration, changes in hydrological regimes, microbiological contamination (Paul \& Meyer, 2001). Therefore, their monitoring must be done through the evaluation of reliable and adequate indicators such as biological indicators (Diomandé et al., 2009). Because of their sedentariness, their great diversity and their variable tolerance to pollution and degradation of these environments, macro invertebrates are good tools for assessing the quality of water and aquatic systems (Moisan $\&$ Pelletier, 2011). The presence or absence of a species and the specific diversity are therefore indicative of good or bad water quality. The main orders of aquatic insects belonging to this category of organisms are as follows, Ephemeroptera, Plecoptera, Trichoptera, Diptera, Coleoptera, Megaloptera, Hemiptera, Odonata and Lepidoptera (Gagnon \& Pedneau, 2006). Some of these cosmopolitan organisms like the Diptera are able to survive in environments subject to significant pollution and are recognized as tolerant to a wide range of disturbances especially organic and sedimentary pollution types. However, in Côte d'Ivoire, the Diptera are little known and the only work done in the rivers was limited to those of (Dejoux, 1981) on the systematic and ecological aspect of Diptera (Chironomidae) while (Diomandé et al., 2009) and (Edia et al., 2010) conducted studies on watercourses to make a faunistic inventory of aquatic insects. Also, (Nathalie Mary, 1999) made an analysis of the pollution of New Caledonia's rivers to the analysis of the relative abundance of Diptera Chironomidae. However, little information exists on Diptera and their importance in the knowledge of the ecological status of aquatic ecosystems in Ivorian urban areas. The general objective of this study is 
to determine the state of biotic integrity of urban aquatic ecosystems of Daloa (Central-West of Côte d'Ivoire) from Diptera. To achieve this, we will (i) make an inventory of the Diptera settlement and (ii) assess the pollution status of each station.

\section{MATERIAL AND METHODS}

\section{Field of study}

This study was carried out in the city of Daloa in westcentral Côte d'Ivoire between the parallels $6^{\circ} 30^{\prime} 00$ " and 7 ${ }^{\circ} 00^{\prime} 00$ " north latitude and between the meridian $6^{\circ} 00^{\prime} 00$ ' and $6^{\circ} 30^{\prime} 00$ " west longitude (Figure 1). In 2014, the city of Daloa had 275,277 inhabitants and 42 neighborhoods with an area of 5,305 hectares, corresponding to a density of 52 inhabitants / km2 (INS-RGPH, 2014). The region of Daloa is characterized by an Attiean-type climate with a transitional regime between the equatorial climate and the tropical climate. The temperature oscillates between $18^{\circ} \mathrm{C}$ and $36^{\circ} \mathrm{C}$. The climate is hot and humid with a rainfall of between 1000 and $1500 \mathrm{~mm} /$ year. There are two seasons during the year in this region: the rainy season, from April to October and the dry season from November to February. The town of Daloa is located in the mesophilic forest sector of the Guinean forest whose predominant climax is the semi-deciduous moist dense forest (N'guessan et al., 2014).

\section{Sampling procedure}

A total of 72 sampling points spread over 24 stations composed of four channels $(\mathrm{CN})$, four fish ponds (EP), four rice ponds (ER), four ponds (MA), four lakes (LA) and four brooks (RU) were selected based on their accessibility and the human activities to which they were subject. Benthic macro invertebrates were collected from 24 stations in two campagnes. L'échantillonnage was performed using the kicknet (250 .mu.m mesh size) according to method SASS (South African Scoring System) (Dickens \& Graham, 2002).The samples were harvested by submerging the troubled net and dragging it in the water column over a distance of 2 meters corresponding to $1 \mathrm{~m}^{2}(2 \times 0.5 \mathrm{~m})$ of sample area for 2 minutes. The sediment organisms were harvested using a Van Veen stainless steel grab. At each site, three (03) sediment samples corresponding to a total area of $0.15 \mathrm{~m}^{2}$ were collected. All samples were stored in pill containers and fixed with $70 \%$ alcohol and then returned to the laboratory. In the laboratory, the samples obtained were sieved, and the harvested individuals, sorted under a binocular magnifying glass, counted and identified at the lowest possible taxonomic level by combining the appropriate determination keys (Brown, 1994; Dejoux, 1981; Forcellini et al., 2015; Mary, 2017).

\section{Data analysis}

The taxonomic richness of the different stations and the abundance of macro invertebrate taxa have been calculated (F, 2003). The diversity of urban ecosystems was determined by the Shannon $\mathrm{H}$ index: $\mathrm{H}^{\prime}=-\Sigma((\mathrm{Ni} / \mathrm{N}) \mathrm{x} \ln$ $(\mathrm{Ni} / \mathrm{N})$ ); with $\mathrm{Ni}$ : number of individuals of a given species and $\mathrm{N}$ : total number of individuals. In addition, the degree of organization of the media was highlighted by the Pioucha equitability $\mathrm{J}=\mathrm{H}$ '/ Hmax $=\mathrm{H}^{\prime} / \log 2 \mathrm{~S}$; with S: number of species observed. The assessment of the ecological quality of urban ecosystems was made using the Diptera index. The Diptera index (\% D) of a station is the ratio of the number of Diptera individuals present to the total number of individuals sampled at a given station (Nathalie Mary, 1999). According to (Winner et al., 1980), the relative percentage value will determine three (3) categories of sites : - D $\geq 75 \%$ : highly polluted sites; - $20 \%$ $<\mathrm{D}<75 \%$ : polluted sites;- D $\leq 20 \%$ : moderately polluted sites. The data obtained were processed using Xlstat 2016 and PAST Version 3.14 software.

\section{RESULTS AND DISCUSSION}

A total of 1987 individuals belonging to 16 families, 34 genera and 53 taxa (Table 1) were counted in all stations studied. Parmiles Diptera, families of Chironomidae and Culicidae are best represented with 25 taxa and 8 taxa respectively. Then come Ceratopogonidae (4 taxa), Muscidae (2 taxa), Psychodidae (2 taxa), Simuliidae (2 taxa), Anthomyiidae, Cecidomyidae, Tenidae, Dolichopodidae, Empididae, Liboniidae, Phoridae, Stratiomyidae, Tabanidae and Tipulidae with one taxon each. Chironomidae with $82.79 \%$ Diptera (1645 individuals) are the first most abundant family. Ceratopogonidae are in second place with $7.5 \%$ of Diptera (149 individuals). Culicidae have a relative abundance of $3.52 \%$ (70 individuals) while Simulidae record 3.02\% (60 individuals) of Diptera. The other families are both very sparse and very infrequent (Tabanidae: 13 individuals, Stratiomyidae and Psychodidae: 11 individuals each, Muscidae: 8 individuals, Limoniidae: 7 individuals, Tipulidae: 3 individuals, Anthomyiidae, Cecidomyidae, Dixidae and Dolichopodidae: 2 individuals each and Empididae, Phoridae: 1 individual) (Figure 2).

The spatial variations of Shannon index $\left(\mathrm{H}^{\prime}\right)$ and equitability $(\mathrm{J})$ are shown in (Figure 3 ). The value of $\mathrm{H}^{\prime}$ varies from 3.15 bits (CN1) to 2.71 bit (CN2) in the channels, from 3.36 bit (EP4) to 2.40 bit (EP2) in fish ponds, from 3.31 bit (ER3) to 1.26 bit (ER1) in rice ponds, 3.49 bit (MA1) at 1.75 bit (MA3) in ponds, from 2.79 bit (LA2) to 1.41 bit (LA1) in lakes and from 3.55 bit (RU2) to 2.75 bit (RU1) ) in the streams. Quant à la valeur de J, elle évolue de 0,68 (CN4) à $0,80(\mathrm{CN} 3)$ dans les canaux, de 0,64 (EP2) à 0,86 (EP4) dans les étangs piscicoles, de 0,35 (ER1) à 0,76 (ER3) dans les étangs rizicoles, de 0,46 (MA3) à 0,91 (MA4) dans les mares, de 0,36 (LA4) à 0,67 (LA2) dans les lacs, et de 0,69 (RU1) à 0,43 (RU3) dans les ruisseaux. Il n'y a pas de differences significatives entre les indices de diversité calculés pour les stations étudiées (Test de Kruskal-Wallis $\mathrm{p}>0$, 05). The calculation of the Diptera indices shows that the fish pond (EP1) has the highest Diptera index $(52.67 \%)$ while the lowest $(0.46 \%)$ is recorded at the rice pond (ER1). The stations (EP1, EP4, MA1, MA2, MA3, MA4, LA2, RU3 and RU4) have Diptera indices ranging between $20.63 \%$ and $52.67 \%$, reflecting pollution of the media. On the other hand, the 
stations (CN1, CN2, CN3, CN4, ER1, ER2, ER3, ER4, LA1, LA3, LA4, RU1 and RU2) have lower Diptera percent values between $0.46 \%$ and $18,61 \%$ describing moderately polluted stations (Figure 4).

Table 1. Taxonomic composition in Diptera.

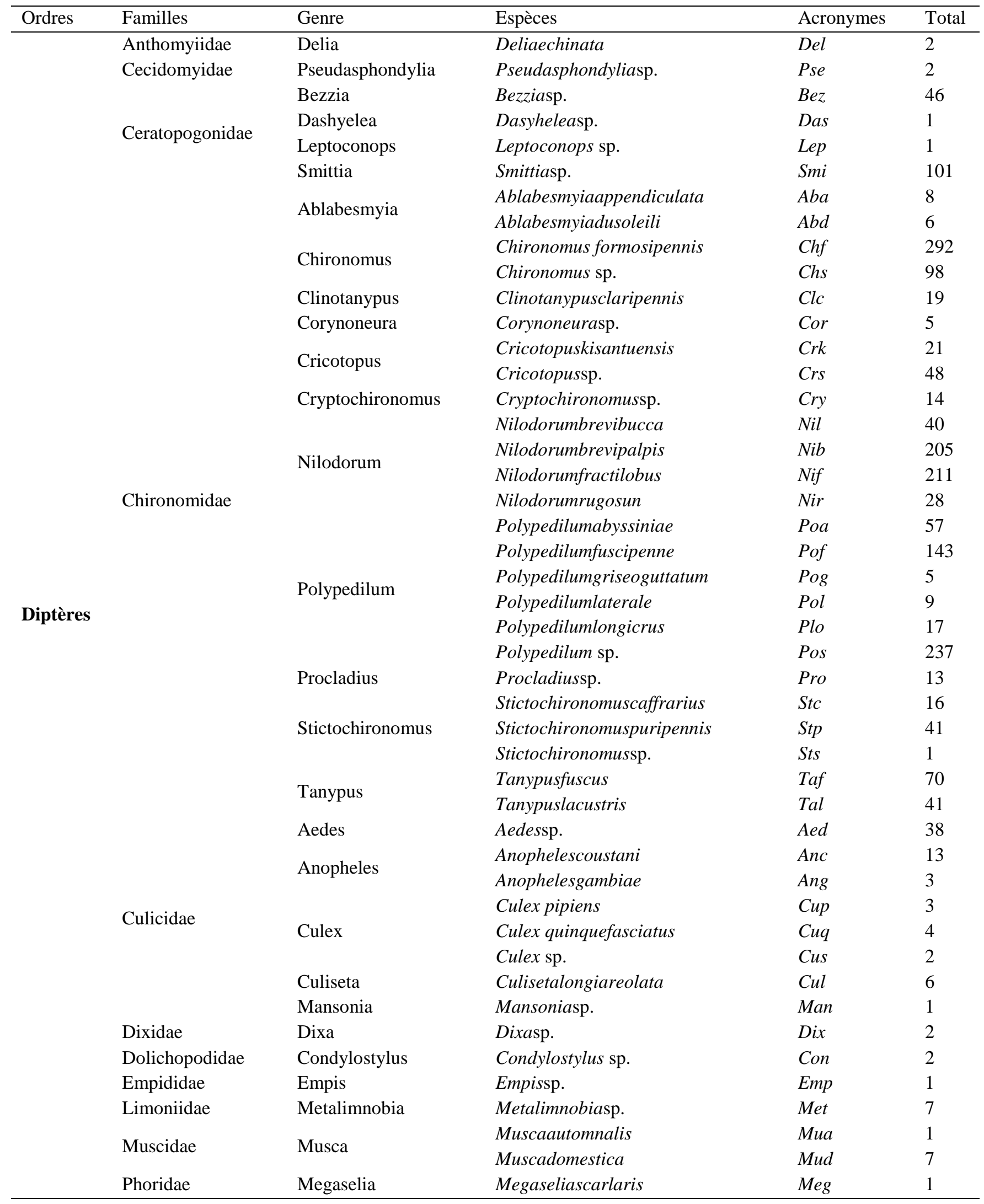




\begin{tabular}{llllll}
\hline & \multirow{2}{*}{ Psychodidae } & \multirow{2}{*}{ Clogmia } & Clogmiaalbipunctata & Clo & 5 \\
& & Clogmia sp. & Cls & 6 \\
& & Paracnephia & Paracnephiasp. & Par & 12 \\
& Simuliidae & Simulium & Simuliumdamnosum & Sim & 48 \\
& Stratiomyidae & Odontomyia & Odontomyiasp. & Odo & 11 \\
& Tabanidae & Tabanus & Tabanussp. & Tab & 13 \\
& Tipulidae & Conosia & Conosiaivrorata & Coi & 3 \\
Total & 16 & & & & 1987 \\
\hline
\end{tabular}

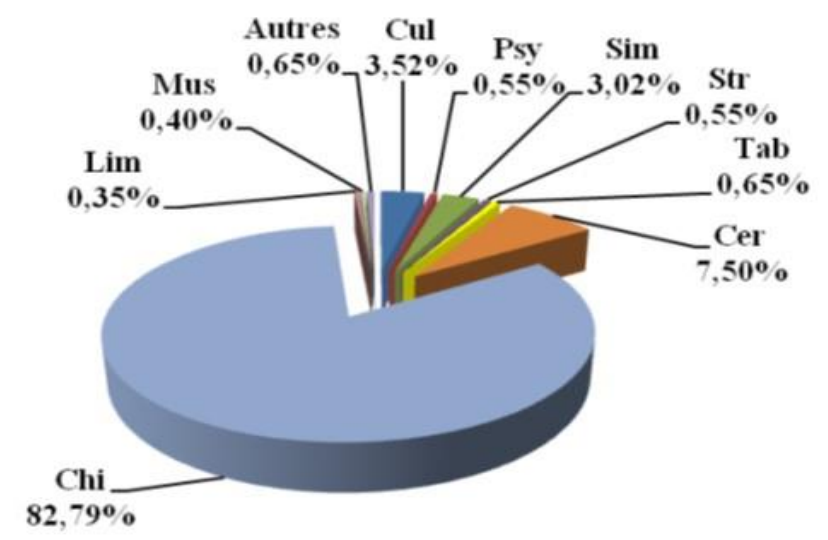

Figure 2. Abundance of Diptera in the studied stations; Cul: Culicidae; Psy: Psychodidae; Sim: Simulidae; Str: Stratiomyidae; Tab: Tabanidae; Cer: Ceratopogonidae; Chi: Chironomidae; Lim: Limoniidae; Mus: Muscidae.

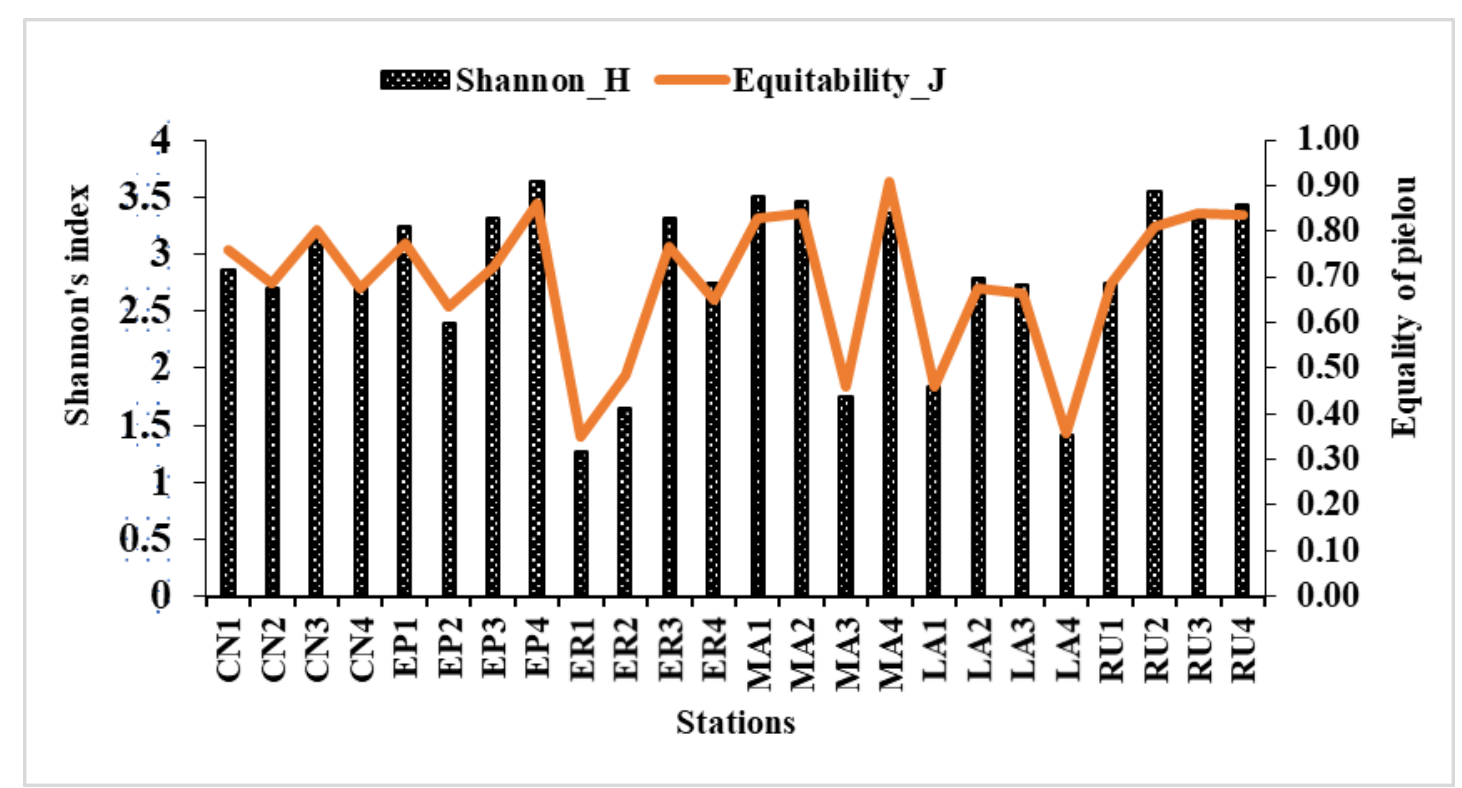

Figure 3. Spatial Variations in the Shannon Diversity Index $(H)$ of Macro-Invertebrate Communities in Aquatic Ecosystems $(\mathrm{CN}=$ Channels, $\mathrm{EP}=$ Fish Ponds, $\mathrm{ER}=$ Rice Ponds, $\mathrm{MA}=$ Mares, $\mathrm{LA}=$ Lakes and $\mathrm{RU}=$ Stream $)$ from Daloa City. KW: Kruskal-Wallis. 


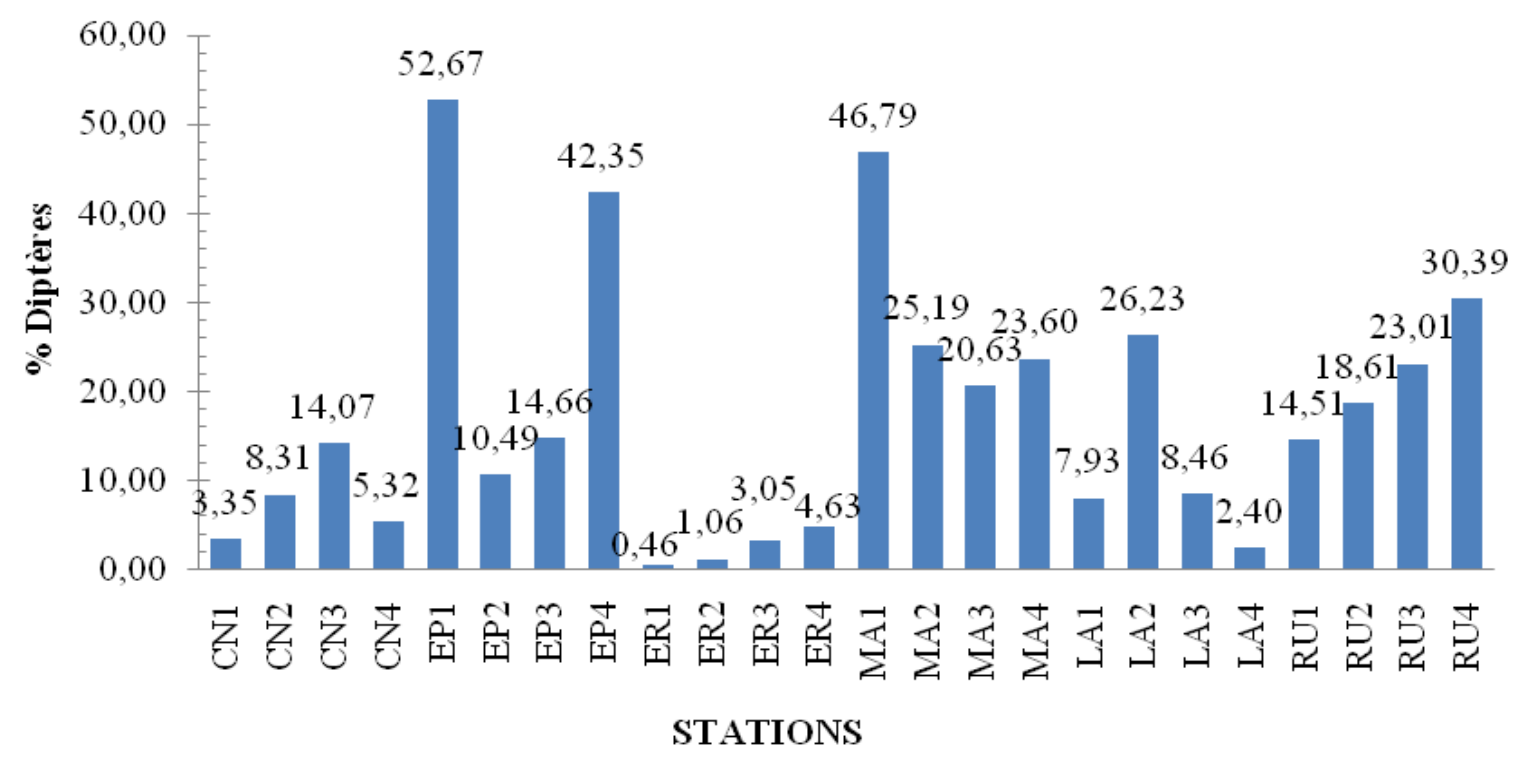

Figure 4. Spatial variation of the Diptera index.

The analysis of the communities of the studied environments made it possible to note an important taxonomic diversity with 1987 individuals of Diptera distributed in 53 taxa and 16 families. The most diverse family is that of Chironomidae with 25 taxa. This result is similar to that of (Kabré, Ille, \& Guenda, 2000) carried out in the Bagré dam lake in the center of the country (Burkina Faso) where a dominance of Chironomidae at the wetland benthos is recorded. Moreover, this dominance is linked to the fact that this family includes a large number of subfamilies, tribes, genera and species living in very diverse habitats and with great ecological plasticity (Mathuriau, 2000). In addition, the diversity of Diptera is thought to be attributable to situations at sampling sites that are often close to areas with farms and vegetables, which would increase the nutrients available for the growth of Diptera larvae (Rosa et al., 2011). Thus, the spatial variation in the abundance of these Diptera harvested in the stations could be attributed to the influence of human activities on these environments. The analysis of community diversity from Shannon's diversity indices $(\mathrm{H})$ and Piélou's Equitability $(\mathrm{J})$ shows that the Diptera communities of rice ponds are the most relatively diversified and balanced $(\mathrm{H} '=1 ? 71$ and, J $=0.96$ ), while those of fish ponds with little diversity and poor equilibrium $(\mathrm{H}=0.06, \mathrm{~J}=0.09)(\mathrm{Dajoz}, 2000)$. This result is associated with the impact of domestic effluents on the structures of the different communities (Mamert et al.,2000). Finally, the Diptera index calculated for the different stations showed that the fish ponds (EP1, EP4), the ponds (MA1, MA2, MA3, and MA4), the lake (LA2) and the streams (RU3, RU4) are polluted. In organic matter, in contrast, canals, rice ponds, lakes (LA1, LA3, and LA4) and streams (RU1, RU2) have low Diptera percent values and describe sites with medium organic matter. This pollution could be lack of special maintenance after all the anthropogenic pressures along the banks of the respective shores. Namely waste produced by animals that regularly come to drink from it, washing and car washes, livestock effluents and agricultural residues (watering of contiguous nurseries). These environments would have favored explosive developments of Diptera populations.

\section{CONCLUSION}

This study addressed issues related to the biotic integrity of Daloa's urban aquatic ecosystems from Diptera. The Diptera stands in these media are quite diverse with 53 Diptera taxa belonging to 16 families collected from the 24 sampling stations. The Diptera indices show that some aquatic environments of Daloa (EP1, EP4, MA1, MA2, MA3, MA4, LA2, RU3 and RU4) are polluted by the effluents resulting from anthropic activities exerted near these environments. However, other sites (CN1, CN2, CN3, CN4, ER1, ER2, ER3, ER4, LA1, LA3, LA4, RU1 and RU2) are less disturbed by pollution.

\section{ACKNOWLEDGMENT}

The authors express sincere thanks to the head of the Laboratoire de Biodiversité et Ecologie Tropicale, UFR de l'Environnement, Université Jean Lorougnon Guédé (Daloa) for the facilities provided to carry out this research work.

\section{REFERENCE}

Brown, D. S. (1994). Freshwater snails of Africa and their medical importance: CRC press. pp.1-673.

Dajoz, R. (2000). Précis d'Écologie. 7ème éd. Paris, Éditions Dunod. pp.1-615.

Davies, B., Biggs, J., Williams, P., Whitfield, M., Nicolet, P., Sear, D., Maund, S. (2008). Comparative biodiversity of aquatic habitats in the European 
agricultural landscape. Agriculture, Ecosystems \& Environment, 125(1-4), 1-8.

Dejoux, C., Elouard, J.M., Forge, P. and Maslin, J.L. (1981). Les Chironomidae. In : Catalogue iconographique des insectes aquatiques de Côte d'Ivoire. Orstom, 151-178.

Dickens, C. W., \& Graham, P. (2002). The South African Scoring System (SASS) version 5 rapid bioassessment method for rivers. African Journal of Aquatic Science, 27(1), 1-10.

Diomandé, D., Bony, K., Edia, O., Konan, K. F., \& Gourène, G. (2009). Diversité des macroinvertébrés benthiques de la rivière Agnéby (Côte d'Ivoire; Afrique de l'Ouest). European Journal of Scientific Research, 35(3), 368-377.

Edia, E., Gevrey, M., Ouattara, A., Brosse, S., Gourène, G., \& Lek, S. (2010). Patterning and predicting aquatic insect richness in four West-African coastal rivers using artificial neural networks. Knowledge and Management of Aquatic Ecosystems, 398, pp.1-6.

F, R. (2003). Elément d'écologie : Ecologie fondamentale. Dunos, (éd.), Paris, 2-190.

Forcellini, M., Mathieu, C., \& Merigoux, S. (2015). Atlas des macroinvertébrés des eaux douces de l'île de La Réunion. Office de l'eau Réunion, pp.1-137.

Gagnon, E., \& Pedneau, J. (2006). Surveillance Volontaire (SurVol) Benthos, guide du volontaire, programme de surveillance volontaire des petits cours d'eau. CVRB, Québec. Canada, pp.1-32.

Gire. (2001). Etat des Lieux des Ressources en Eau du Burkina Faso et de leur Cadre de Gestion. Version finale, Mai 2001. Direction Générale des Ressources en Eau : Ouagadougou.pp.1-252.

INS-RGPH, (2014).

Donnée démographiqueetéconomique des

Sociolocalités. Résultatsglobaux, Sécrétariat Technique Permanent, Abidjan.

Kabré, T., Illé, A., \& Guenda, W. (2000). Inventaire et étude de la densité de distribution des insectes du benthos des deux lacs de barrage de Bagré. Science et Technique, série Sciences Naturelles et Agronomie, 24(2), 121-132.

Mamert, O. F., Hubert, Z. T. S., Ernest, K., Tchatcho, N., Lié, N., \& Siméon, T. Influence of municipal and industrial pollution on the diversity and the structure of benthic macro-invertebrates community of an urban river in Douala, Cameroon.

Mary, N. (1999). Caractérisations physico-chimique et biologique des cours d'eau de la Nouvelle-Calédonie. Proposition d'un indice biotique fondé sur l'étude des macroinvertébrés benthiques. Université Française du Pacifique. pp.1-181

Mary, N. (2017). Les macroinvertébrés benthiques des cours d'eau de la Nouvelle-Calédonie. Guide d'identification. Version révisée 2017, DAVAR Nouvelle-Calédonie. ed. OEIL, CNRT. pp.1-181.

Mathuriau. (2000). Les macro-invertébrés des cours d'eau andins du Sud-est de la Colombie : écologie et bioindication. Thèse de Doctorat, Université Paul Sabatier, Toulouse, France, 1-390.

Moisan, J., \& Pelletier, L. (2011). Protocole d'échantillonnage des macroinvertébrés benthiques d'eau douce du Québec: cours d'eau peu profonds à substrat meuble: Plan Saint-Laurent pour un développement durable, pp.1-39.

N'guessan, A., N'Guessan, K., Kouassi, K., Kouamé, N., \& N'Guessan, P. (2014). Dynamique des populations du foreur des tiges du cacaoyer, Eulophonotus myrmeleon Felder (Lépidoptère: Cossidae) dans la région du HautSassandra en Côte d'ivoire. Journal of Applied Biosciences, 83, 7606-7614.

Oertli, B., Biggs, J., Céréghino, R., Grillas, P., Joly, P., \& Lachavanne, J.B. (2005). Conservation and monitoring of pond biodiversity: introduction. Aquatic Conservation: Marine and Freshwater Ecosystems, 15(6), 535-540.

Paul, M. J., \& Meyer, J. L. (2001). Streams in the urban landscape. Annual Review of Ecology and Systematics, 32(1), 333-365.

Rosa, V., de Oliveira, V.C., \& Alves, R. d. G. (2011). Structure and spatial distribution of the Chironomidae community in mesohabitats in a first order stream at the Poço D'Anta Municipal Biological Reserve in Brazil. Journal of Insect Science, 11(1), 36.

Winner, R., Boesel, M., \& Farrell, M. (1980). Insect community structure as an index of heavy-metal pollution in lotic ecosystems. Canadian Journal of Fisheries and Aquatic Sciences, 37(4), 647-655. 